\title{
Adriaan Reland and Dutch Scholarship on Islam
}

\author{
Scholarly and Religious Visions of the Muslim Pilgrimage
}

\author{
Richardvan Leeuwen
}

The development of Dutch Oriental studies and the study of Islam was from the beginning of the seventeenth century connected with the religious debates between the Catholic Church in Rome and the various Protestant communities in northern Europe. The Protestant scholars subverted the monopoly held by the Vatican on the study of Islam and its polemics against the 'false' faith, which was often based on incorrect presuppositions. Debates about Islam became rapidly entangled with opinions about religion in general or about Catholic doctrines and practices more specifically. In their anti-Catholic attitude the Protestant scholars even harboured some sympathy for certain aspects of Islam, although they emphasised that Muhammad should not be considered an authentic prophet. They argued for a more objective examination of Islam, to be able to counter the rivalling faith more effectively. This tendency can be clearly observed in publications about Islam in the Dutch Republic in the seventeenth and eighteenth centuries.

One may argue that the Protestant trend in Oriental studies culminated in Adriaan Reland's famous compendium of Islamic doctrines De religione Mohammedica, which was published in 1705 and was subsequently translated into various languages. The second edition of the book, published in 1717, which was based on authentic Arabic manuscript sources, not only contained a concise but detailed survey of the main tenets and practices of Islam, but was also supplemented with a section in which the main European misperceptions of Islam were corrected. More significantly, in his preface Reland proposed a new approach to the European study of Islam detached from the conventional polemics propagated by the Catholic Church, which were based on medieval mystifications and erroneous interpretations of texts. In Reland's view, the new approach should not only be based on Arabic sources, but also on a revised vision of Islam as a faith. Islam should no longer be seen merely as a misleading counterpart of Christianity, but rather as a self-contained religion, which, although not 'true' in the doctrinal sense, still deserved unprejudiced, neutral evaluation. ${ }^{1}$

1 Reland, De religione Mohammedica libri duo, 1717. 
Reland can be considered one of the prominent exponents of the rich tradition of Dutch Oriental scholarship represented by Thomas Erpenius (1584-1624), Jacobus Golius (1596-1667) and Levinus Warner (1618-1665), who worked mainly in the fields of grammar, lexicography and the collection of manuscripts. However, these scholars were not the only intellectual background from which Reland benefited for his work. In the shadow of these great figures others were working on collecting and processing information about the Levant and Islam which was not so much based on the disclosure of new manuscript sources, but rather on gathering information and contributing to the conceptualisation of the field and the complex scholarly and religious debates. It is these scholars which co-shaped the environment in which Reland could flourish. In this contribution we will focus on several works by Dutch travellers and scholars who contributed decisively to seventeenth century scholarship about Islam in several ways and thereby paved the way for Reland's efforts. To limit the field, we will concentrate on one particular component in Islam which was especially relevant for the new 'discovery' of the Orient in the early phases of globalisation and which reveals the way in which religious debates within Christianity and about Islam converged: the Hajj, or pilgrimage to Mecca. ${ }^{2}$

Because Mecca was difficult to reach for non-Muslims, from the Middle Ages on the town was covered in mysteries and myths. When the contacts between Europe and the Muslim world intensified in the fifteenth and sixteenth centuries and the number of European travellers to the Levant increased, the interest in the significance of Mecca as the centre of Islam and of the Muslim pilgrimage increased as well. Travellers described the ceremonies at the departure of the pilgrimage caravans from Cairo and Damascus, triggering the imagination of their European audience. Portugal became involved in the transport over sea of pilgrims from Asia, and Portuguese travellers visited the Muslim holy places as the first Europeans. Gradually, other Europeans succeeded in reaching Mecca, either incognito, or in the retinue of their Muslim masters. Through their reports information about Mecca and the Hajj trickled into Europe. In spite of the increase of knowledge about Islam through the often accurate accounts of travellers, it is surprising that the information about

2 See for a survey of Dutch Oriental studies: Vrolijk and Van Leeuwen, Arabic Studies in the Netherlands; see also Bevilacqua, The Republic of Arabic Letters. 
Mecca and the Hajj should have been absorbed in European scholarship at a relatively slow pace. Although reports by travellers debunked the myth that Muhammad's coffin floated in the air between magnets in Mecca, and that the aim of the Hajj was the visiting of Muhammad's tomb, these convictions were still not completely extinct in the eighteenth century. ${ }^{3}$

Although the Dutch East India Company, the voc, was involved in the struggle for the control of the Yemenite coastal towns and acquired a foothold in the Arabian peninsula at an early stage, there are no indications that Dutch merchants attempted to penetrate into the Arabian desert and explore the Muslim holy cities. The earliest reference to the Hajj in a Dutch text can be found in the account of the Flemish traveller Joos van Ghistele (1446-1516), who visited the Levant in the years 1481-1485. In Cairo Van Ghistele witnessed the departure of the pilgrimage caravan to Mecca, which he embeds in an extensive excursion into the history and geography of Arabia, mainly based on the work of the German traveller Bernhard von Breydenbach (Peregrinatio in terram sanctam, 1486). Van Ghistele repeats the legend that Muhammad is buried in Mecca and that his coffin is suspended between magnets. He asks a guardsman who accompanies him to describe Muhammad's grave. After the description ('precious jewels', 'countless lanterns') the guardsman adds that he has heard this information from a pilgrim who had pulled out his eyes after 'beholding this most holy place, as everyone should do who covets to see this tomb'. When Van Ghistele asks him about the suspended sarcophagus, the guardsman answers that he has heard about this story, but does not know if it is true, although he understood that it used to be suspended in the past. Van Ghistele further refers to the annual caravans from Barbary, Persia, Egypt and Syria, the many precious gifts carried by them, and the presentation of the kiswa, the cloth covering the Kaba inside the Holy Mosque. He observes the festivities in Cairo and adds that every Muslim who does not visit the grave of Muhammad is doomed. He also mentions the custom of Muslims to wash themselves before appearing before the Prophet, in the conviction that in this way they not only cleanse their body, but also purify their soul. Van Ghistele refrains from comments on these observations and his description is in no way polemical. ${ }^{4}$

Another Flemish traveller who refers to the Hajj in the account of his journey to Spain and Morocco, is Nicolaes Cleynaerts, or Clenardus (1493-1542), a

3 Travellers included Ludovico Varthema (1470-1517; in Mecca in 1503; book published in 1510), Vincent Le Blanc (1586), and Johann Wild (1585-1619?; in Mecca in 1607; book published in 1613; it is not certain that the latter two accounts are authentic); Joseph Pitts (app. 1663-1739?; in Mecca app. 1684; book published in 1704/1731). See Ralli, Christians at Mecca; Freeth and Winstone, Explorers of Arabia from the Renaissance to the Victorian era.

4 Zeebout, Tvoyage van Mher Joos van Ghistele, p. 26. 
Catholic priest who in 1531 departed to Spain to learn Arabic and debate with the Muslims about their religious doctrines. In the passages about his stay in Spain he remarks that Muslims have the obligation to visit Mount 'Pharon' once in their life, 'where, as they piddle, Abraham used to pray'. ${ }^{5}$ The number of pilgrims should always be 6oo.ooo; when the number is less, they are supplemented by angels. This is according to their holy book, the 'nonsensebook Suna. ${ }^{6}$ During the pilgrimage they visit the mountain 'Araphet', where, as they piddle, Adam and Eve were reunited after their fall from paradise. Clenardus describes the collecting of the pebbles in some detail:

At the foot of Mount Araphet is a sandy and plain desert where they spend the night with thousands simultaneously and diligently collect 63 pebbles, while chaplains walk around to warn them not to break big stones into small ones in order to reach the number more quickly. This would harm their religion as a whole. They put the pebbles in a small bag and go to Mina, where Abraham, as they claim, passed when he intended to sacrifice his son Isaäc. There are three pillars here surrounded with high heaps of pebbles, because the pilgrims, who spend three days here, throw seven pebbles every day while whispering salutes, and in this way dispense of the 63 pebbles. The origin of this ritual is that Isaäc, when he followed his father to be sacrificed, was addressed by the devil and advised not to obey his father: But Isaäc remained obedient and took seven stones to repel the devil. This happened on three occasions. I think this an 'aping' of the temptation of Christ, when the devil was repelled three times, too. ${ }^{7}$

Clenardus' attitude towards Islam is still determined by the Catholic stereotype of the false prophet and a revelatory book (here called 'Suna') disqualified as a 'collection of jokes', a ridiculous text full of stupidities and false claims with regard to the hereafter. The rituals of the pilgrimage are rejected as 'foolish' and 'ridiculous' and based on 'thick-skinned lies.8 ${ }^{8}$ On the other hand, he has the 'modern' opinion that an open debate and knowledge of their textual sources could cure Muslims from their mistakes. In the words of Clenardus:

5 Clenard, p. 284.

6 Ibid.

7 Clenard, Reys door verscheyde landen gedaen by den factoor van den doorluchtighesten koning van Portugal Emanuel de XIV, pp. 284-287.

8 Clenard, pp. 284-287, passim. 
It would be highly desirable that some people should be found willing to enlighten these blind people, the more so since they already believe that Christ is the word of God, born from the Virgin Mary, without a father made of flesh. The major problem is only that they believe that Mahomet was a greater prophet than Christ. This would have to be refuted [...] There are some who have written against them in Latin, but what is the use of writing and speaking to someone in a language that he does not understand? I hope to strive for this and for that purpose travel through Africa, because the books that are required for this are not available here. With this intention I have departed for Fez with my servant where the Mahometan religion is greatly respected and where many law-scholars reside, in the hope of acquiring the books and other things that I need. ${ }^{9}$

Clenardus reached Fez in 1540 and succeeded in collecting books and debating with scholars before he was expelled in 1541. He died in Granada impoverished and downtrodden in 1542.

The early Dutch accounts of travellers to the Levant include a book by Jan Somer about his journey to Constantinople and Cairo, among other places, in 1590-1592. In his description of the Ottoman capital he recounts that he has heard from Christians that many wealthy Turks sell all their possessions to be able to complete the journey to Muhammad's grave. When they have seen the grave, the most sacred place that can be beheld, they pull out their eyes and continue to live as beggars:

Back in Constantinople where they live they roam through the streets to demand bread for the sake of God. They do not take money and pass by the doors singing a song in honour of Mahomet's grave, indicating that they have visited the grave of Mahomet. They can be recognised by their clothes as well, since they are poorly clad, like the Lazarists in the Netherlands. Usually they pass by the doors in groups of ten or twelve persons, singing together. I have seen this not once but twenty times in Constantinople and have heard it being confirmed by Christians as true..$^{10}$

The second print of the book is supplemented with a short overview of the religions customs, doctrines and laws of the Turks, compiled by an anonymous Christian slave, who 'has lived there as a prisoner for thirteen years'. The

$9 \quad$ Ibid., pp. $286-287$.

10 The book was published in two editions, with identical title data: Somer, Zee en landt reyse gedaen naer de Levante, 1st edn. (1649), pp. 29-30. 
description of the pilgrimage here is somewhat contradictory to his earlier statements, because the urge to visit the holy places is attributed to the desire for profit rather than to religious zeal. Somer recounts that to build Mecca, Muhammad asked the surrounding mountains to deliver stones. However, Mount Arafat arrived late, when Mecca had already been built:

Because the mountain Araphat-dagh was slower than the others because she came from far away, and when she saw that Mecca had already been built and her stones were no longer required, she began to weep bitterly. When Mahomet saw her weeping and heard the reason for her sadness, he said: Rejoice and do not be sad and put your contribution here: whoever will not have prayed on this stone, his pilgrimage will be invalid and useless. And Mahomet kicked the stone with his foot and drew water from it suitable for drinking. He called it Abzomzem, that is, purifying water, from which all pilgrims take a quantity to their homes in small vessels. And when someone dies, the clothes in which the dead body will be covered will be sprinkled with this water to forgive all his sins. ${ }^{11}$

He further explains that the body of Muhammad is not buried in Mecca, but that a statue of him is placed in a corner of the 'temple' which is kissed by the pilgrims. Somer concludes by observing that the Muslims believe in this kind of 'foolishness' and 'lies', but he assures the reader that his spokesman has told the truth. From this description it is clear that Somer's source had not personally attended the ceremonies of the Hajj, but the information does not seem to be derived from conventional opinions. ${ }^{12}$

Simon Oomius (1630-1706)

The reports by Van Ghistele, Clenardus and Somer reveal a rather primitive knowledge of Islam, which is based more on vague sources than on a systematic study of texts. Apart from the accounts of travellers who saw Mecca with their own eyes, more Arabic sources were gradually made available within the networks of Protestant Orientalists. An important event in this respect was the publication of fragments from the history of Abu al-Faraj, which contained a detailed description of the ritual and which appeared in a translation

11 Ibid., second edition (1649), p. 34; my translation.

12 Ibid. 
by the English Orientalist Edward Pococke in $1650 . .^{13}$ That Dutch scholars of the mid-seventeenth century had access to the most recent knowledge about Islam gathered within these networks is shown by a number of remarkable books. A significant work, written by the theologian Simon Oomius, a pupil of the famous theologian Gisbertus Voetius (1589-1676), is Het geopende en wederleyde muhammedisdom ('Muhammedanism explained and refuted'), published in 1663. In this work Oomius gives a general survey of the life of Muhammad and the history of Islam, before presenting a systematic discussion of Islamic doctrines. ${ }^{14}$

Oomius first of all remarks that many 'fables' about Islam are spread due to the accounts of travellers and others, and that there is a need for reliable information from Muslim authors and scholars. Only after this information is obtained can the claims and doctrines of the Muslims be revealed to be a hotchpotch of fables and heresies. This is especially important because Christians reproach each other for holding opinions similar to those of Muhammad and because some adopt his pernicious ideas. The Calvinists have been compared to the Turks and the Remonstrants have been vilified by reformed Protestants as 'propagators of the Turkish doctrine'. This is incorrect, according to Oomius: it is rather the doctrines of the Roman Catholics and Socinians which most resemble those of Islam. Throughout his book Oomius gives arguments for a combined refutation of Islam, Papism and Socinianism, which are seen as manifestations of the same evil.

Oomius adopts the conviction, popular in Protestant circles, that the expansion of the Muslims should be seen as a punishment by God, caused by the sinfulness and negligence of the Christians. Nevertheless, Muhammad is evidently a 'false prophet', a 'belligerent rapist', and a 'blasphemer'. He is compared with Pope Boniface III, who had himself declared head of the Church in 6o7. Muhammad and Boniface were both imposters and had similar opinions. Like Muhammad, the pope proscribed the examination of the source texts; both usurped worldly powers; both believed in charity, fasting, pilgrimage, and the merit of good works; both based their doctrines on ancient heresies; both endorsed the 'magical' effects of water as a means to wash away sins; and both indulged in carnal pleasures. Therefore, both deserved the qualification 'Antichrist'. Still, although he was an imposter, Muhammad was superior to the pope, because he was courageous and because his doctrines were chaste, forbade gambling and the theatre, and propagated frugality, charity, the

13 Edward Pococke, Specimen historiae Arabum, Oxford, $165^{\circ}$.

14 Oomius, Het geopende of wederleyde Muhammedisdom. 
education of children, personal merit, the virtuousness of priests, obedience to the authorities, and good treatment of animals.

This complex attitude towards Islam, in which the Protestant dissatisfaction with Catholicism and the Islamic doctrines converge, is reflected in Oomius' discussion of Mecca and the Hajj. Here he reveals a considerable knowledge of the sources that were available at the time, although he could not read Arabic and therefore was unable to disclose new source material. He presents an extensive overview of opinions on the historical descriptions of Mecca and emphasised debated issues, such as the location of Muhammad's grave, referring to a large number of European Orientalists and translated fragments from Arabic authors, such as the Christian historians Elmacinus (Jirjis al-Makīn, 1205-1273; translated by Erpenius) and Abū al-Faraj (Bar Hebraeus, 1226-1286; translated by Pococke), and the theologian Abū Hāmid al-Ghazāil (d. 1111; fragments of his work were already known in the fifteenth century; some were translated by Hottinger and Pococke, see below). His European sources include works by Breydenbach, mentioned above, the Protestant traveller Salomon Schweigger (1551-1662), who worked on a translation of the Qur'an, the Scottish traveller William Lithgow (1582-1645), the universalist scholar Guillaume Postel (1510-1581) and the Swiss scholar and theologian Johann Heinrich Hottinger (1620-1667). He refers to the translations of the Qurān by Theodore Bibliander (1509-1564) and André Du Ryer (1580-166o or 1672), which had been translated into Dutch in 1641 and 1657.15 This impressive array of sources indicates the upsurge of Oriental scholarship within the Protestant networks in the first half of the seventeenth century.

Oomius begins his discussion of the Hajj by observing that Muhammad has made the pilgrimage to his grave obligatory for pious believers and 'monks' at a fixed time. The journey to Mecca is meant as expiation for sins, although according to some a visit to Jerusalem and Bethlehem is also required for complete forgiveness. The custom to visit the grave of the prophet is strictly obeyed and every year tens of thousands of pilgrims set out for Mecca. Oomius mentions the legends about the construction of the holy temple by angels, Adam, Abraham and Ishmael, and adds that according to some historians it was a place where the planets were worshipped. He elaborates on the black stone in the Ka'ba, which originally came from paradise and was returned there temporarily during the Flood. He mentions the rebellion of the Carmathians, the changing of the colour of the black stone, which was originally white and enlightened the whole of Mecca, the role of Abraham and Hagar, and the kissing of the stone by the pilgrims. Finally, he remarks that Muhammad has

15 See for more information about these scholars: Bevilacqua, Republic of Arabic Letters. 
commanded the believers to ask forgiveness from the stone, weeping and sighing, and to beg for help against their enemies. He concludes by saying that although Muhammad rejected idolatry, he still preserved the customs and ceremonies of the idolaters, and can therefore be accused of superstition. ${ }^{16}$

Oomius subsequently lists the various components of the pilgrimage ritual, and here his tone becomes increasingly polemical. He compares Islamic customs with the 'Papist' superstitions. After all, the 'Romans' also have their pilgrimages to Jerusalem, Rome, Compostela and Loreto, or to temples, tombs, relics and statues, to receive blessing, help and mercy. The Muslims, too, have the custom to visit graves, where priests collect large amounts of money as guards and caretakers. It is for financial gain that priests, Papists and other 'belly-servants' propagate pilgrimage with godless lies and fables.

As a doctrine connected with the expiation of sins, the Hajj is compared with the Catholic custom of indulgences, which was one of the main grievances of the Protestants against the Vatican, and with the concept of holy years, initiated by the popes to lure the believers to come to Rome. Pope Boniface viII, a 'true monster', of whom it is said that he 'sneaked in like a fox, reigned like a lion, and died like a dog, ${ }^{17}$ installed the custom of holy years in which the believers were summoned to visit Rome and which were declared with increasing frequency. And 'who knows what else will come from these harpies and devourers of the goods and blood of the people.18 But God has punished them for their greed: After a number of holy years plagues broke out and severe defeats were suffered against the Turks. The idea of holy years emerged simultaneously with the rise of the Turks, who profited from them. Oomius concludes: 'We reject Muhammadan and Papist pilgrimages because we know that God has not connected His help and mercy to a place on earth.19

Oomius' treatise about Islam is not well-known, probably because it was written in Dutch and because it was not based on new, original sources, but it is arguably the most complete example of the entwinement of scholarly and religious debates in Europe in the seventeenth century. His argument is built on a large corpus of literature, which was clearly accessible in the Dutch Republic at the time.

$16 \quad$ Ibid., pp. $45^{1-472 .}$

17 Ibid., p. 469 .

18 Ibid., pp. 469-472.

19 Ibid., p. 471. 
A second work containing an extensive overview of knowledge about Mecca and the Hajj is the geographic-ethnological encyclopaedia by the geographer Olfert Dapper (1636-1689), entitled Naukeurige beschryving van Asie ('A precise description of Asia'). The book, which pertains to the discipline of geography, but still pays substantial attention to religion, was published in Amsterdam in 1680 and includes a detailed map of the Arabian peninsula. ${ }^{20}$

Dapper's encyclopaedia gives a detailed survey of the history and doctrines of Islam. The Hajj is described in a separate chapter about the town of Mecca and in the section about the faith. Dapper begins by defining the 'Kaba' as the 'chapel' in the 'temple' of Mecca, and the term 'Haram', which 'indicates the boundaries around the city which are indicated with towers at five, seven or ten miles distance from the city. In this area it is not permitted to kill living creatures or attack an enemy'. In the centre of the temple 'Alharam' ('Beyth Allah Haram') stands the chapel surrounded by the spaces for the four sects. The Ka'ba has a silver door that can be reached by using a wheeled stairway. It is covered with red and white silk on the inside and a silk cloth on the outside, which is replaced every year by the sultan of Cairo. The Kaba was built by Adam and restored by Abraham. Muhammad destroyed the idols that had become objects of veneration during the course of time, and removed the altar stones around them. Dapper also mentions the Zamzam well, whose water is used by the pilgrims for the sake of health and forgiveness, and the black stone, which, according to the fictions of Arabic authors (here al-Zamakhshari, via Pococke) was brought from paradise by Adam. The stone was initially white, but turned black after it was touched by a menstruating woman, or, according to others, by sinners. ${ }^{21}$

The pilgrimage, which is extensively described by Dapper, was, according to him, initiated by Abraham. In the Muslim world every year five caravans leave from Cairo, Constantinople, Damascus, Persia, the Maghreb and the Mughal empire, under the command of an 'Emir Hazjzj' and accompanied by troops. The pilgrimage is partly undertaken to obtain immunity against punishment for sins, comparable to Catholic indulgences. The pilgrims sing songs from the Qurān or enact rituals of love and mercy. Two days before arrival, in 'Rabak' (Rābigh) pilgrims strip their clothes and cover themselves in two sheets and wooden shoes, promising not to shave, trade, kill, fight or curse for eight days. They follow an imam walking around the temple, reciting 'ridiculous' prayers and performing dances with 'ridiculous' movements of the shoulders. Then

20 Dapper, Naukeurige beschrijving van Asie.
21 Ibid., pp. 42-45, 19-20. 
they walk around the Kaba seven times, walk to Mina and Arafat and throw stones. They believe that on Mount Arafat Adam looked for Eve after the fall from paradise. To complete the pilgrimage, the Muslims visit the grave of the prophet in Medina. Dapper adds that the Turks burst out laughing when they hear about the story of the suspended coffin.

In his description of the Hajj rituals Dapper, who did not know Arabic and never travelled to the Levant, refers to a large number of sources, both European and Arabic (in translation). ${ }^{22}$ Some of these works had been published only recently, and Dapper's references show not only how precise and well-versed he was, but also that Dutch scholars were in the forefront of this kind of research. His description is very elaborate and detailed and mentions many transliterated Arabic terms and names. His approach also reveals his broad vision of his discipline, because he does not confine himself to geographical descriptions, but acknowledges the importance of culture, socioethnic communities and, of course, religion.

Dapper's work shows a clear break with the polemical tropes of the medieval discourse about Islam, but it is not free of polemical overtones. A number of rituals are disqualified as 'ridiculous' and he is apparently intrigued by the observation that every year after the sacrificial feast (Bayram) heavy rains fall which rinse clean the place of the sacrifice. These rains fall every year after the third day of the ritual, although the Muslim calendar moves ten days annually. Dapper observes that the pilgrims loosen their turbans and throw them out to touch the presents of the Muslim kings to Mecca, since 'the Mohammedans treat these gifts with no less respect than the Papists attribute to their relics'. The pilgrimage as a whole is nothing more than a ruse to bind the believers to the faith: 'The notorious Prophet Mohammed, who was a conjurer and a sly hypocrite, has confirmed the ancient custom of the pilgrimage, to seduce people and win their hearts, to reinforce his dominion'. Dapper closes his survey with a quotation from the theologian Abū Hiâmid al-Ghazālī, that the pilgrimage has no meaning and is no more than a decree of God. He quotes Abū al-Faraj as well:

Pilgrimage is only an image or sketch of the exit from the world, and an example of the journey to the future world. Most customs enacted during the pilgrimage have no other purpose than to test man, to see if he is prepared to obey what is imposed upon him. ${ }^{23}$

\footnotetext{
22 Sources include: Abū al-Faraj, al-Zamakhsharī, al-Jannābī, al-Ghazālī, Abū al-Fidā', Șafy al-Dīn, Euthymius, Ibn al-Athīr, Gabriel Sionita, Jacob ben Sidi Ali, Hottinger, al-Bayḍāwī and Maimonides. 
The books by Oomius and Dapper show how, in the second half of the seventeenth century, efforts were made to glean knowledge about Islam from a broad reservoir of sources and collect it in extensive surveys. These works are a prelude to the important compendium De religione Mohammedica (1705; 1717) by Adriaan Reland (1676-1718) who was professor of Oriental languages in Utrecht. In the book, which is considered a landmark in scholarship of Islam because of its relatively objective purport, Reland dedicates a separate chapter to the Hajj. He first explains that five obligations are required for a valid performance of the Hajj: the intention to travel to Mecca and the required religious vow; standing at Arafat; shaving or shortening the hair in Mina; the circumambulation of the Kaba; and, finally, running to and fro between al-Safa and al-Marwa. The details of the ritual are added in a footnote, explaining the procedures day by day. The circumambulation (tawäf) is described in detail: the first three rounds should be completed running, shaking the shoulders, followed by the kissing of the black stone. Reland adds that according to Abū al-Faraj's history 'heretics' laugh at the tawäf, which they compare to an 'ox walking on the threshing floor.'24 In the second part of his book, Reland corrects the false opinions that Muslims think that they will be cleansed of their sins by washing their body and that they travel to Mecca to see the tomb of the prophet. ${ }^{25}$ It is mainly this critical component which strengthened Reland's reputation as an apologist of Islam, an accusation that he rejects emphatically in his foreword. Still, for both his admirers and his adversaries he retained the reputation of having a (too) positive evaluation of Islam, turning him into a point of reference in the debates that followed throughout the eighteenth century.

Although Reland's treatise is usually praised for its objectivity, his description of the Hajj is not deprived of polemical comments. Reland emphasizes that the rituals of the pilgrimage go back to pre-Islamic times and are associated with Abraham the Patriarch. Rituals like running, washing and throwing stones were practised by the Arabs before the time of Muhammad, but subsequently fell into abeyance. They were restored by the Prophet in an adapted form. For instance, pilgrims used to perform the ceremonies naked, but Muhammad obliged them to cover themselves. Reland confirms that the pilgrimage is only legitimized by a decree from God and not by a 'natural light' or 'healthy reason'. In his evaluation some criticism shines through:

24 References are to: Reland, Verhandeling van de godsdienst der Mahometaanen, pp. 81-89.

25 Ibid., pp. 90-91. 
... and that God wanted to impose matters such as these, whose meaning, or the reason why they are imposed by God, cannot be comprehended by human reason, intending that humans should learn to obey God in everything, not because they understand that it is just and adequate with regard to God, but only because God has ordained it. ${ }^{26}$

Reland refers to Pococke's quotation of al-Ghazālī, who says that the ritual has no connection with the mind or the heart, or with nature, and that the mind should not look for a meaning. It is merely an obligation, which 'should not be scrutinized by the mind or the soul.'. ${ }^{27}$ Reland also mentions Maimonides' 'teacher Abū Shafar', who has said that these ceremonies are not absurd, but are based on 'natural reason': Man should be in harmony with the celestial bodies and for that purpose 'cleanse themselves and move in circles'. ${ }^{28}$

All these observations indicate an interesting turn in the debate, that is, the tendency to separate knowledge from polemics aiming at a more objective evaluation. Reland is not averse to criticizing Islam, but a compendium of Islamic doctrines is not the same as a book against Islam. Although he feels obliged to defend his approach in his preface against accusations of endorsing Islam, in his survey he does not embark upon polemics against the Muslims or, for that matter, the Catholic Church. Significantly, there is no comparison between the Hajj and Catholic forms of pilgrimage. In this work Reland sets the tone for many later works about Islam in Protestant countries. He argues that it is necessary to present Islam 'not tarnished or covered with the fumes of calumny or errors, but as it is taught in the churches and schools of the Mohammedans', not in order to endorse Islam, but rather 'to convince our own minds of the falsity [of Islam], if not the minds of the Turks themselves'. And, Islam should not be seen as mere folly: 'Mohammedans are not as mad or possessed as we should like to think. Sound understanding is distributed equally among mankind'. Hitherto Islam was studied only by polemicists who 'did not combat the Mohammedan faith but their own illusions and shadows' ${ }^{29}$

In the Dutch Republic his approach was followed in the great survey of world religions edited by Bernard and Picart, Cérémonies et coutumes religieuses de toutes peoples du monde (Amsterdam, 1723-1743), and in the remarkable biography of Muhammad written by Johannes Nomsz, Mohammed, of de hervorming der Arabieren ('Muhammad, or the reformation of the Arabs', Amsterdam,

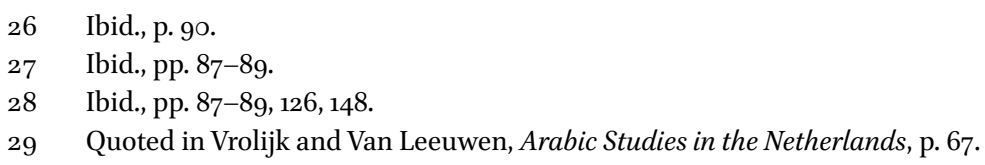


1780), in which the pilgrimage to Mecca is a major narrative theme. In England, Reland's treatise was translated in a collection entitled Four treatises concerning the doctrine, discipline, and worship of the Mahometans (London, 1722), and it served as a reference for the famous new translation of the Qurān by George Sale (1734). In France, it was the source of inspiration of the biography of Muhammad by Comte de Boulainvilliers (La vie de Mahomed, 1730).

The importance of Reland's De religione Mohammedica with regard to the Hajj does not end here. A very interesting addition to the 1717 edition of the book is an engraving of the holy mosque in Mecca. The engraving is the first detailed and reliable image of the mosque in a European publication, after a number of mainly fictional representations in earlier works. For his engraving Reland used a rather mysterious oil painting that was brought from the Levant by the Swedish diplomat and Orientalist Michael Eneman, who on his return journey to Sweden visited Reland in Utrecht. ${ }^{30}$ The painting is unique and mysterious, because it definitely looks European, but cannot be made by a European painter, because Europeans had no access to Mecca. However, in the Ottoman Empire there was no tradition of oil painting and the origin of the work, which conveys a precise image of the holy mosque, remains unknown. It may have been the work of a European painter residing in Istanbul or an Ottoman Christian painter versed in oil techniques. Whatever may have been the case, Reland obtained permission to copy the painting, adapting the perspective somewhat because 'Turks are not very accurate as far as proportions are concerned'.31

Reland's engraving remained for a long time the standard representation of the holy mosque. It was reproduced in the English translation of his work in Four treatises, mentioned above, and in the important account by Joseph Pitts of his journey to Mecca in the retinue of his Muslim master (1731). ${ }^{32}$ It acquired a remarkable descendant: a lacquer plate showing the holy mosque in Mecca. The plate, which is clearly based on Reland's representation, was probably fabricated in Japan in the eighteenth century and subsequently presented to an administrator of the Dutch Indies. There are two copies extant, one which ended up in Jerusalem, and another held by the museum of Groningen in the

\footnotetext{
$30 \quad$ See about Eneman: Östlund, 'A Lutheran in the Holy Land'.

31 See for the painting and Reland's engraving: Tütüncü, 'The Uppsala Mecca Painting'. Another representation was published soon afterwards in Johann Bernhard Fischer von Erlach, Entwurf einer historischen Architektur (1721). The provenance of this representation is unknown; see Grabar, 'A Preliminary Note on Two Eighteenth-Century Representations of Mecca and Medina'.

32 See Auchterlone, Encountering Islam; Joseph Pitts: An English Slave in 17th-Century Algiers and Mecca.
} 
Netherlands. This peculiar object shows not only how influential Reland's work was, but also how Dutch Oriental scholarship, connected with Dutch trade, was integrated in the early phases of globalisation. ${ }^{33}$

\section{5}

\section{Conclusion}

This concise overview makes clear to what extent Dutch Oriental studies were at the interface between economic and political interests and religious debates. The Islamic pilgrimage, as a phenomenon that was linked to the increasingly intimate contacts between Europe and the Muslim world, became a focus of interest both within the process of globalisation - as exemplified by the travellers' accounts - and scholarly debates. It was seen as a ritual in which several aspects of Islam converged and which was gradually purged of its medieval mystifications. Apart from this, it was seen as a doctrine which highlighted the controversies between Catholics and Protestants and gained prominence in the inter-Christian polemics. The Hajj not only symbolised the differences between Islam and Christianity, but also the differences between the northern European Protestants and the Roman Church. In this respect it is illustrative of the change in the judgement and appreciation of Islam: in Protestant Oriental studies as practised by Reland, Islam is not so much a reprehensible Christian sect as an autonomous religion deserving a thorough and unbiased examination. Although scholars such as Oomius and Dapper did not disclose new source material and retained a certain polemical attitude, they prepared the way for Reland's 'modern' vision of religion which remained influential in European perceptions of Islam.

\section{Bibliography}

\section{Sources}

Auchterlone, P., Encountering Islam; Joseph Pitts: An English Slave in 17th-Century Algiers and Mecca. A Critical Edition, with Biographical Introduction and Notes, of Joseph Pitts of Exeter's A Faithful Account of the Religion and Manners of the Mahometans, 1731, London, Arabian Publishing, 2012.

Clenard, N., Reys door verscheyde landen gedaen by den factoor van den doorluchtighesten koning van Portugal Emanuel de XIV, Verscheyde voyagien, ofte reysen, gedaen door Jr Joris Van der Does na Constantinopelen, heer Adriaen de Vlaming na

33 Schweizer and Shalem, 'A Japanese Lacquer Plaque of the Haram in Mecca'. 
Hierusalem. Den factoor van den koning van Portugal, Nicolaes Clenard na Turckyen etc, Dordrecht, Vincent Caeynacx, 1652.

Dapper, O., Naukeurige beschrijving van Asie, behelsende de gewesten van Mesopotamie, Babylonie, Assyrie, Anatolie, of Klein Asië: beneffens eene volkome beschrijving van gansch gelukkigh, woest, en Petreesch of steenigh Arabie, Amsterdam, Jacob van Meurs, 168 o.

Fischer von Erlach, J.B., Entwurf einer historischen Architektur, Vienna, 1721 (facsimile ed. Harenberg Kommunikation, Dortmund 1978).

Oomius, S., Het geopende of wederleyde Muhammedisdom of Turckdom, Amsterdam, Wilem van Beaumont, 1663 (reprint: Landelijke Stichting ter Bevordering van de Staatkundig Gereformeerde Beginselen, Wijk en Aalburg, 2010).

Pococke, E., Specimen historiae Arabum, sive Gregorii Abul Farajii Malatiensis De origine \& moribus Arabum succincta..., Oxford, H. Hall, 165 O.

Reland, A., Verhandeling van de godsdienst der Mahometaanen, Utrecht, Willem Broedelet, 1718.

Somer, J., Zee en landt reyse gedaen naer de Levante. Als Italien, Candien, Cypres, Egypten, Rhodes, Archipelago, Turckyen; en wederom door Duytslant ... eerste en tweede druk (first and second editions), Amsterdam, Joost Hartgers, 1649.

Zeebout, A., Tvoyage van MherJoos van Ghistele, edited by R.J.G.A.A. Gaspar, Hilversum, Verloren, 1998.

\section{Studies}

Bevilacqua, A., The Republic of Arabic letters; Islam and the European Enlightenment, Cambridge, MA and London, The Belknap Press of Harvard University Press, 2018.

Freeth, Z., and V. Winstone, Explorers of Arabia from the Renaissance to the Victorian era, London etc., George Allen \& Unwin, 1978.

Grabar, O., 'A Preliminary Note on Two Eighteenth-Century Representations of Mecca and Medina', Jerusalem Studies in Arabic and Islam, vol. 25, 2001, pp. 268-274.

Östlund, J., 'A Lutheran in the Holy Land: Michael Eneman's Journey, 1711-1712' in J.A. Hayden and N. Matar (eds), Through the Eyes of the Beholder, Leiden, Brill, 2012, pp. 207-224.

Ralli, A., Christians at Mecca, London, William Heinemann, 1909.

Schweizer, A. and A. Shalem, 'A Japanese Lacquer Plaque of the Haram in Mecca in the L.A. Mayer Memorial Museum, Jerusalem', Ars orientalis, vol. 39 (Globalizing cultures: art and mobility in the eigtheenth century), 2010, pp. 148-173.

Tütüncü, M., 'The Uppsala Mecca Painting: A New Source for the Cultural Topography and Historiography for Mecca', in L. Mols, and M. Buitelaar (eds), Hajj: Global Interactions Through Pilgrimage, Leiden, National Museum of Ethnology, and Sidestone Press, 2015, pp. 137-162.

Vrolijk, A., and R. van Leeuwen, Arabic Studies in the Netherlands: A Short History in Portraits, 1580-1950, translated by A. Hamilton, Leiden and Boston, Brill, 2014. 